DOI 10.14746/ssp.2014.2.9

Maria GOŁDA-SOBCZAK

Instytut Kultury Europejskiej UAM w Gnieźnie

\title{
Zgromadzenia publiczne w polskim systemie prawnym i ich znaczenie dla kultury i sztuki
}

$\mathrm{W}$ Olność zgromadzeń należy do tych wolności i praw, które były dość wcześnie gwarantowane zarówno w konstytucjach, jak i w aktach prawa międzynarodowego. Zaliczano ją do wolności i praw politycznych, łącząc zazwyczaj z wolnością zrzeszania się i zderzając z wolnością wypowiedzi. W systemie prawnym Rady Europy, na gruncie europejskiej Konwencji o ochronie praw człowieka i podstawowych wolności, sporządzonej w Rzymie 4 listopada 1950 r., zmienionej następnie protokołami nr 3, 5 i 8 oraz uzupełnionej Protokołem nr 2 (Dz. U. 1993, Nr 61, poz. 284 ze zm.; dalej: EKPC), Europejski Trybunał Praw Człowieka w Strasburgu (dalej: ETPC) stwierdzał, że prawo zgromadzania się jest ściśle związane $\mathrm{z}$ gwarantowaną $\mathrm{w}$ art. 10 EKPC swobodą wypowiedzi oraz wynikającą z art. 9 EKPC wolnością myśli, sumienia i wyznania (van Dijk, van Hoof, 1998, s. 429; Wróbel, 2010, 693; wyrok ETPC Young, James, Webster przeciwko Zjednoczonemu Królestwu). Wskazuje się, że wolność zgromadzeń stanowi jeden z istotnych elementów współczesnego standardu państwa demokratycznego $\mathrm{w}$ sferze podstawowych praw i wolności obywatelskich. ETPC, dążąc do zdefiniowania prawa do swobodnego zgromadzania się, stwierdził, że jest to prawo fundamentalne w społeczeństwie demokratycznym i podobnie jak wolność wypowiedzi stanowi jedną z podstaw takiego społeczeństwa (wyrok ETPC Kazantseva przeciwko Rosji). Genezy jej poszukiwano w okresie Wielkiej Rewolucji Francuskiej, zauważając, że w Konstytucji francuskiej z 3 września 1791 r. wolność ta występuje w tytule I obejmującym ,fundamentalne dyspozycje gwarantowane przez Konstytucję” jako „wolność obywateli do gromadzenia się pokojowego i bez broni, przy respektowaniu ustaw porządkowych" (Czarny, Naleziński, 1998, s. 10). Współczesnego czytelnika uderza fakt, że w lakonicznym sformułowaniu twórcy Konstytucji francuskiej objęli wszystkie elementy tak ważne dla wolności zgromadzeń, a więc, że jest to zebranie pokojowe, jego uczestnicy nie mają broni i że chcą respektować ustawy porządkowe. 
W prawie - a może raczej wolności - do zgromadzeń widzi się współcześnie prawo podmiotowe oraz najczęściej jedną z zasad porządku prawnoustrojowego. Wolność zgromadzeń gwarantują zarówno dokumenty polityczne, jak i akty prawa międzynarodowego. Formułuje ją art. 20 Powszechnej deklaracji praw człowieka (Rotfeld, 1989, s. 18), zapewnia art. 11 EKPC, a także Międzynarodowy pakt praw obywatelskich i politycznych ${ }^{1}$.

Konstytucja RP z 1997 r. nie przydaje wolności zgromadzeń takiej wagi, jak wolności prasy i innych środków społecznego przekazu, która znalazła się w art. 14 w rozdziale I Rzeczpospolita, obejmującym zasady ustrojowe państwa, statuując ją w rozdziale II w art. 57 Konstytucji w grupie wolności i praw politycznych, jako pierwszą z tych wolności i praw. Konstytucja z 1997 r. odróżnia wolność zgromadzeń (art. 57) od wolności zrzeszania się (art. 58). Oddzielność tych regulacji zdaje się potwierdzać odmienność treści normatywnych obu tych wolności mimo niewątpliwie i historycznie potwierdzonej wspólnoty ideowej. Zauważa się przy tym, że obydwie wolności, tj. wolność zgromadzeń i wolność zrzeszania się, są przejawami idei wolności myśli i opinii. W ten sposób ujmował tę kwestię już art. 11 Deklaracji praw człowieka i obywatela z 26 sierpnia 1789 r. Zdefiniowanie wolności zgromadzeń wydaje się zabiegiem trudnym. Wyodrębnia się jednak elementy, które odróżniają wolność zgromadzeń od wolności zrzeszania się (stowarzyszania się). Wskazuje się, że zgromadzenie publiczne ma charakter okazjonalny, w odróżnieniu od zrzeszenia, które zakłada istnienie względnie trwałych stosunków między jego członkami. Zgromadzenie natomiast nie tworzy żadnej trwałej więzi między uczestnikami. Identyfikacja członków stowarzyszenia jest stosunkowo łatwa, chyba że takie stowarzyszenie ma mieć charakter tajny i jego istnienie nie jest komunikowane władzom publicznym, ale i wówczas władze takowego stowarzyszenia orientują się kto jest jego członkiem. Uczestnictwo w zgromadzeniu publicznym z natury rzeczy jest anonimowe. Ta anonimowość uczestników zgromadzenia publicznego jest ważnym elementem treści normatywnej konstytucyjnej wolności zgromadzeń (Robert, 1988, s. 569; Israel, 1998, s. 492; wyroku TK z 10 listopada 2004 r.). W uzasadnieniu późniejszego wyroku TK, z 10 lipca 2008 r. (P 15/08, OTK-A 2008, nr 6, poz. 105, Lexis.pl nr 1925181), stwierdzono, że „,zgro-

1 Międzynarodowy pakt praw obywatelskich i politycznych otwarty do podpisu w Nowym Jorku 19 grudnia 1966 r. (Dz. U. 1977, Nr 38, poz. 167). 
madzenie publiczne ma charakter okazjonalny, co rzutuje na charakter więzi występującej między jego uczestnikami. To różni zgromadzenie od stowarzyszenia, które zakłada istnienie względnie trwałych relacji między jego członkami. Zgromadzenie nie tworzy trwałej więzi między jego uczestnikami; pozostają oni grupą ludzi anonimowych. W stowarzyszeniu, a także podczas wszelkich zgromadzeń czy zebrań o charakterze prywatnym ustalenie tożsamości osoby uczestniczącej jest czymś oczywistym lub co najmniej w pełni dopuszczalnym i możliwym, natomiast uczestnictwo w zgromadzeniu publicznym nie jest określone imiennie. Uczestnictwo $\mathrm{w}$ zebraniu prywatnym jest nominatywne i osobiste, a w zgromadzeniu publicznym - anonimowe. Tak pojmowany anonimowy charakter uczestnictwa w zgromadzeniu publicznym jest ważnym elementem treści normatywnej konstytucyjnej wolności zgromadzeń, jest przejawem wolności, z której jednostka (obywatel) może skorzystać”. W systemie prawnym Rady Europy wskazuje się, że funkcją prawa do zgromadzania się jest ochrona prawa wyrażania osobistych przekonań, zapewnienia forum dla publicznej debaty i otwartego protestu (wyroki ETPC: Ezelin przeciwko Francji, Éva Molnár przeciwko Węgrom, Djavit przeciwko Turcji).

Wolność zgromadzeń postrzega się jako jedno z podstawowych politycznych praw człowieka. Podmiotem tego prawa jest jednostka, a treścią m.in. możliwość rozwoju osobowości, wspólnie z innymi, także wówczas, gdy rozumienie rozwoju osobowości nie odpowiada innym podmiotom życia publicznego czy aktualnie wykonującym władzę publiczną przedstawicielom tej władzy. To znaczy, że władza publiczna jest zobowiązana do gwarancji realizacji tej wolności, niezależnie od wyznawanych przekonań partyjnopolitycznych, bo wolność zgromadzeń jest wartością konstytucyjną, a nie wartością określaną przez demokratycznie legitymowaną, w danym momencie sprawującą władzę większość polityczną (wyrok TK z 18 stycznia 2006 r.).

Jakkolwiek zgromadzenie publiczne z natury rzeczy ma charakter okazjonalny, to jednak nie jest zazwyczaj przypadkowym zgrupowaniem osób, lecz ma charakter intencjonalny, zwoływane jest przez organizatorów i ma swój konkretny cel, którym jest zazwyczaj zaprotestowanie przeciwko jakiejś sytuacji o charakterze politycznym, społecznym bądź gospodarczym, wyrażenie opinii bądź idei, wystąpienie w obronie określonych interesów, z którymi identyfikują się jego uczestnicy. Zgromadzenie w rozumieniu art. 57 Konstytucji nie jest przypadkowe. Ustawa zasadnicza zapewnia nie tylko wolność zgromadzeń, ale w pierwszym rzędzie wolność organizowania ich i uczestniczenia w nich. Jest rzeczą 
jasną, że nie każde zebranie ludzi jest zgromadzeniem o charakterze publicznym. Ustawodawca polski wyraźnie odróżnia zgromadzenia publiczne - normowane treścią prawa o zgromadzeniach ${ }^{2}$ - od imprez masowych, regulowanych przepisami o bezpieczeństwie imprez masowych ${ }^{3}$. W odróżnieniu od zgromadzeń publicznych imprezy masowe oczywiście nie mają na celu wymiany myśli i idei, czyli debaty publicznej, lecz uczestnictwo w określonych wydarzeniach. Warto zauważyć, że ustawodawca w treści art. 3 ust. 1 ustawy z 20 marca 2009 r. o bezpieczeństwie imprez masowych zastosował dość szerokie wyłączenia określonych imprez spod pojęcia imprezy masowej, stwierdzając, że nie podlegają ustawie i nie są imprezami masowymi w rozumieniu ustawy imprezy: organizowane w teatrach, operach, operetkach, filharmoniach, kinach, muzeach, bibliotekach, domach kultury i galeriach sztuki lub w innych podobnych obiektach; organizowane w szkołach i placówkach oświatowych przez zarządzających tymi szkołami i placówkami; organizowane w ramach współzawodnictwa sportowego dzieci i młodzieży; sportowe organizowane dla sportowców niepełnosprawnych; sportu powszechnego o charakterze rekreacji ruchowej, ogólnodostępnym i nieodpłatnym, organizowane na terenie otwartym; zamknięte organizowane przez pracodawców dla ich pracowników.

Fakt, że zgromadzenia publiczne i imprezy masowe regulowane są przez odrębne ustawy oraz że inaczej określone są obowiązki ich organizatorów, nie upoważnia do sformułowania wniosku, że wolność zgromadzeń określona w treści art. 57 Konstytucji nie dotyczy imprez masowych. Wniosek taki jest całkowicie nieuzasadniony i bezpodstawny.

Uczestnikami zgromadzenia w rozumieniu ustawy o zgromadzeniach nie będą widzowie spektaklu teatralnego, seansu filmowego, kibice na stadionie sportowym, wierni uczestniczący we mszy świętej. Jasną jest rzecza, że uczestnicy tego typu spotkań przybywają na nie w określonym celu, chcąc poznać kunszt aktora czy reżysera, rozerwać się, oglądając przedstawienie teatralne, bądź zapłakać w ciemności w trakcie seansu filmowego. Wierni podczas nabożeństwa chcą wspólnie z innymi współwyznawcami poczuć wspólnotę religii, doznać uniesienia czy może nawet

2 Ustawa z 5 lipca 1990 r. - Prawo o zgromadzeniach (tekst jedn. Dz. U. 2013, poz. 397).

3 Ustawa z 20 marca 2009 r. o bezpieczeństwie imprez masowych (tekst jedn. Dz. U. 2013, poz. 611 ze zm.). Ustawa ta uchyliła wcześniejszą ustawę z 22 sierpnia 1997 r. o bezpieczeństwie imprez masowych (tekst jedn. Dz. U. 2005, Nr 108, poz. 909 ze zm.). 
ekstazy wynikającej z przeżycia obrządku, z faktu uczestniczenia w kulcie, ewentualnie zademonstrować swoją przynależność do grona wyznawców określonej denominacji, ludzi wybranych, godniejszych, swoich. Kibice na stadionie sportowym identyfikują się z drużyną, odczuwając w mniejszym lub większym stopniu wręcz mistyczną ,plemienną więź” z innymi entuzjastami określonego klubu (Matusewicz, 1990, s. 12; Matusewicz, 1997, s. 171; Gorący, 1992; Pawlak, 1989, s. 21 i n.). Oczywiście wszystkie tego typu spotkania mogą przerodzić się w zgromadzenia publiczne w rozumieniu art. 57 Konstytucji. Taki charakter może przybrać uroczysty pogrzeb znanego polityka, duchownego, wybitnego uczonego bądź artysty. Dobrym przykładem może być pogrzeb Prezydenta Lecha Kaczyńskiego i jego małżonki, ks. Jerzego Popiełuszki, Czesława Miłosza. Uczestnikami zgromadzenia publicznego mogą się stać w określonych okolicznościach uczestnicy spektaklu teatralnego bądź uroczystości religijnej. Jako przykład można by wskazać wystawienie „Dziadów” Adama Mickiewicza w 1968 r. i związane z tym protesty studentów przeciwko cenzurze czy msze święte z udziałem Jana Pawła II. Generalnie są to jednak sytuacje wyjątkowe. Tak więc może się zdarzyć - i w praktyce się zdarza - że zebrania jakiejś grupy ludzi przekształcić się mogą w tzw. zgromadzenia spontaniczne (Bodnar, Ziółkowski, 2008, s. 48). Zgromadzenia spontaniczne stanowią najczęściej reakcję na nieoczekiwane, doniosłe wydarzenie, jakim jest np. zmiana sytuacji politycznej w państwie, podwyżka cen, uświadomienie sobie skutków jakichś działań organów państwowych, przegrana jakiejś drużyny we współzawodnictwie sportowym. Rozpatrując problem zgromadzeń spontanicznych, autorzy skupiają się zwykle na kwestiach wynikających z niewypełnienia obowiązku wcześniejszej notyfikacji odpowiednim władzom publicznym, nie podejmując kwestii, czy i w jakiej mierze do takiego zgromadzenia odnoszą się ogólne przepisy regulujące wolność zgromadzeń. Nakłada się na to delikatny problem świadomości prawnej członków społeczeństwa, który generalnie jest dość niski, a także wpływu, jaki na jednostkę uczestniczącą w spontanicznej demonstracji wywiera tłum (Le Bon, 1986). Tego typu zgromadzenie, z racji swojej spontaniczności, może się łatwo przekształcić w niekontrolowane zamieszki (Kulesza, 1991, s. 12-14). Jakkolwiek prawo o zgromadzeniach nie reguluje kwestii zgromadzeń spontanicznych, to jednak, zdaniem Trybunału Konstytucyjnego (wyrok TK z 10 lipca 2008 r.), taka regulacja wydaje się konieczna, zwłaszcza jeśli się weźmie pod uwagę wytyczne Organizacji Bezpieczeństwa i Współpracy w Europie z 30 marca 2007 r., w których stwierdzono, że w odniesieniu do zgro- 
madzeń spontanicznych ustawa powinna wyraźnie wprowadzać wyjątek od wymogu wcześniejszego zgłoszenia, dając także możliwość natychmiastowej spontanicznej reakcji na określone zdarzenie. Wskazano w nich także, iż spontaniczne zgromadzenia powinny być traktowane ,jako spodziewana, a nie wyjątkowa cecha zdrowej demokracji”, wskazując, że władze powinny chronić i ułatwiać odbywanie spontanicznych zgromadzeń tak długo, jak długo mają one pokojowy charakter. Prawo powinno chronić uczestników, którym zarzuca się udział w nielegalnym zgromadzeniu, jeśli byli nieświadomi nielegalności (Szydło, 2012, s. 145).

Wypada w tym miejscu zauważyć, że w myśl art. 4 pkt 1 i 2 przepisy ustawy prawo o zgromadzeniach nie dotyczą zgromadzeń organizowanych przez organy państwa lub organy samorządu terytorialnego oraz odbywanych w ramach działalności Kościoła katolickiego, innych kościołów oraz związków wyznaniowych. Niewątpliwie chodzi przy tym o te kościoły i związki wyznaniowe, które mają uregulowany status prawny, to znaczy istnieje odrębna ustawa regulująca stosunek państwa do tych kościołów bądź związków wyznaniowych lub też takowy kościół bądź związek został wpisany do rejestru. Wypada jednak zauważyć, że poza wyłączeniami, o jakich mowa w treści art. 4 pkt 1 i 2 ustawy prawo o zgromadzeniach niektóre ustawy szczególne modyfikują zasady odbywania zgromadzeń. Do ustaw tych należą: ustawa z dnia 7 maja 1999 r. o ochronie terenów byłych hitlerowskich obozów zagłady ${ }^{4}$, ustawa $\mathrm{z}$ dnia 20 czerwca 1997 r. prawo o ruchu drogowym ${ }^{5}$, kodeks wyborczy z dnia 5 stycznia $2001 \mathrm{r}$. (w odniesieniu do kampanii wyborczych i zwoływania zgromadzeń, pochodów i manifestacji) ${ }^{6}$ oraz ustawa $z$ dnia 27 lipca 2005 r. prawo o szkolnictwie wyższym ${ }^{7}$. Na tej ostatniej regulacji wypada skupić w tym miejscu nieco uwagi. Otóż w myśl art. 230 ust. 1 wspomnianej ustawy pracownicy uczelni, doktoranci i studenci mają prawo organizowania zgromadzeń na terenie uczelni. Na zorganizowanie zgromadzenia w lokalu uczelni niezbędna jest zgoda rektora. O zamiarze zorganizowania zgromadzenia organizatorzy mają obowiązek zawiadomić rektora na co najmniej 24 godziny przed rozpoczęciem zgromadzenia, jednak w sytuacjach uzasadnionych nagłością sprawy rektor może przyjąć zawiadomienie złożone w krótszym terminie (art. 230 ust. 2). Rektor ma jednak

4 Dz. U. 1999, Nr 41, poz. 412.

T.j. Dz. U. 2012, poz. 1137 ze zm.

6 Dz. U. 2011, Nr 21, poz. 112.

7 T.j. Dz. U. 2012, poz. 572 ze zm. 
obowiązek odmówienia udzielanie zgody, a nawet zakazania zorganizowania i przeprowadzenia zgromadzenia, jeżeli cele lub program zgromadzenia naruszają przepisy prawa. Może także na zgromadzenie delegować swojego przedstawiciela. Przepisy porządkowe dotyczące odbywania zgromadzeń winien określić statut uczelni (art. 230 ust. 3). Organizatorzy zgromadzeń odpowiadają przed organami uczelni za ich przebieg. Jeżeli zgromadzenie przebiega $\mathrm{z}$ naruszeniem przepisów prawa rektor uczelni albo jego przedstawiciel po uprzedzeniu organizatorów rozwiązuje zgromadzenie (art. 230 ust. 7). Treść art. 230 ustawy prawo o szkolnictwie wyższym jest z jednej strony wyrazem autonomii uczelni i władzy rektora (Olejniczak-Szałowska, s. 406), z drugiej świadectwem wolności akademickich (Symonides, s. 407-425). Warto przy tym pamiętać, że ani w treści art. 230, ani w całej ustawie prawo o szkolnictwie wyższym nie ma definicji zgromadzenia $\mathrm{w}$ związku $\mathrm{z}$ tym do jego treści odnosi się niewątpliwie art. 1 ust. 2 prawo o zgromadzeniach, w myśl którego zgromadzeniem jest zgrupowanie co najmniej 15 osób zwołanych w celu wspólnych obrad lub w celu wspólnego wyrażenia stanowiska. Pamiętać przy tym należy, że w myśl art. 1 ust. 2 prawa o zgromadzeniach charakter zgromadzenia mają: demonstracja, manifestacja, marsz, parada, pikieta, protest, przemarsz, wiec, pochód, defilada (Mamak, s. 24).

Wypada zwrócić uwagę, że w myśl ustawy prawo do zorganizowania zgromadzenia mają pracownicy uczelni, a więc zarówno pracownicy dydaktyczni, jak i administracyjni, a także doktoranci i studenci. Prawo to nie przysługuje jednak osobom z zewnątrz, które chciałyby z różnych przyczyn, np. z racji dogodności miejsca, prestiżu, zorganizować takie zgromadzenie na terenie uczelni. Dyskusyjnym się wydaje czy istnieje możliwość udziału w zgromadzeniu zorganizowanym przez podmioty uprawnione w myśl art. 230 ust. 1 prawa o szkolnictwie wyższym osób spoza uczelni. Opowiedzieć się jednak wypada za możliwością udziału w takim zgromadzeniu osób, które nie należą do grupy wskazanej w przywołanym przepisie. Ustawa wyraźnie odróżnia teren uczelni od lokalu uczelni. Lokal uczelni to każde z pomieszczeń znajdujące się w budynkach uczelni. Teren uczelni tworzą budynki z ich pomieszczeniami (lokale uczelni) oraz tereny przynależne do budynków, czyli obszar zewnętrzny należący do uczelni. Należy pamiętać, że teren uczelni określa rektor w porozumieniu z właściwym organem samorządu terytorialnego. Godzi się także przypomnieć, że służby państwowe odpowiedzialne za utrzymanie porządku publicznego i bezpieczeństwa wewnętrznego mogą wkroczyć na teren uczelni - a więc tym bardziej do jej lokali - tylko na 
wezwanie rektora (Ura, s. 430). Tak więc niedopuszczalnym złamaniem wolności akademickiej jest wzywanie przez pracowników administracyjnych takowych służb w celu np. usunięcia samochodu, który na terenie uczelni zaparkował jeden z jej pracowników, ale niewchodzący w skład określonego wydziału użytkującego ten teren. Służby państwowe odpowiedzialne za utrzymanie porządku publicznego i bezpieczeństwa wewnętrznego na teren uczelni mogą wkroczyć z własnej inicjatywy, ale wyłącznie w sytuacji bezpośredniego zagrożenia życia ludzkiego lub klęski żywiołowej, a o wkroczeniu winny zawiadomić niezwłocznie rektora. Obowiązane są także opuścić teren uczelni niezwłocznie po ustaniu przyczyn, które uzasadniły ich wkroczenie na teren uczelni lub na żądanie rektora (art. 227 ust. 1-5 prawa o szkolnictwie wyższym). Do służb, o jakich mowa w art. 227 prawa o szkolnictwie wyższym należy zaliczyć Policję, a w określonych sytuacjach Żandarmerię Wojskową, Straż Graniczną, Agencję Bezpieczeństwa Wewnętrznego, Centralne Biuro Antykorupcyjne, Straż Pożarną. Takiego charakteru nie mają jednak - jak się wydaje - służby ochrony obiektów, a także Straż Miejska, gdyż w ustawie mowa wyraźnie o służbach państwowych (a więc podległych administracji rządowej), a nie o służbach podległych samorządowi bądź podmiotom prywatnym. Dodać na koniec należy, że wspomniany przepis art. 230 prawa o szkolnictwie wyższym dotyczy zarówno uczelni publicznych, jak i niepublicznych. Należy pamiętać, że jeżeli społeczność akademicka ma zamiar zorganizować zgromadzenie poza obrębem uczelni w miejscu publicznym, to wówczas do zgromadzenia tego mają zastosowanie regulacje przewidziane w prawie o zgromadzeniach (Nowakowski, s. 60).

Trybunał Konstytucyjny wskazał, że zgromadzenie jako forma szczególnego sposobu wyrażania poglądów, przekazywania informacji i oddziaływania na postawy innych osób jest niezwykle ważnym środkiem komunikacji międzyludzkiej, w sferze zarówno publicznej, jak i prywatnej, oraz formą uczestnictwa w debacie publicznej, a w konsekwencji - również $\mathrm{w}$ sprawowaniu władzy $\mathrm{w}$ demokratycznym społeczeństwie (wyroki TK: z 18 stycznia 2006 r., z 10 lipca 2008 r.). Celem wolności zgromadzeń jest nie tylko zapewnienie autonomii i samorealizacji jednostki, ale również ochrona procesów komunikacji społecznej niezbędnych do funkcjonowania demokratycznego społeczeństwa. U jej podstaw leży interes publiczny. Wolność zgromadzeń stanowi warunek i konieczną część składową demokracji, a także przesłankę korzystania z innych wolności i praw człowieka związanych ze sferą życia publicznego (wyrok TK z 28 czerwca 2000 r.). Trybunał Konstytucyjny podkreśla więc, że zgro- 
madzenia stanowią zasadniczy element wyrażania demokratycznej opinii publicznej, stwarzając możliwość wpływu na proces polityczny, umożliwiając krytykę i protest, tworząc tym samym część składową deliberacyjnej demokracji bezpośredniej. Wolność zgromadzeń jako postać prowadzenia debaty publicznej, środek artykulacji interesów i poglądów, instrument ochrony mniejszości podnosi poziom legitymizacji i akceptacji rozstrzygnięć podejmowanych przez organy przedstawicielskie i podporządkowany im aparat administracyjno-wykonawczy.

W orzecznictwie Trybunału Konstytucyjnego podkreślono także, że wolność zgromadzeń jest ważna dla porządku politycznego i społecznego oraz przede wszystkim dla mechanizmu przedstawicielskiego, gdyż pełnią one funkcję stabilizacyjną. Polega ona na tym, że publicznie zostają przedstawione i poddane analizie źródła, przyczyny i istota niezadowolenia czy też wyrażona jest krytyka lub negacja obowiązującego porządku prawnego lub społecznego. Wolność zgromadzeń odgrywa zatem istotną rolę jako mechanizm wczesnego ostrzegania, ukazując organom przedstawicielskim i opinii publicznej potencjalne i już istniejące źródła napięć, działanie mechanizmów oraz efektów integracyjnych, i umożliwia odpowiednio wczesną korektę polityki (Wyrok TK z 18 stycznia 2006 r.). W uzasadnieniu wyroku TK z 18 stycznia 2006 r. wskazano, że dzięki zgromadzeniom ,zwiększa się - także przez funkcje kontrolne i opiniotwórcze mediów - możliwość oddziaływania organizacji i grup społecznych na życie publiczne. Zgromadzenia tworzą organizacyjne i funkcjonalne formy realizacji konstytucyjnej wolności słowa i wolności przekazywania i otrzymywania różnorodnych treści, które bez konstytucyjnych gwarancji wolności zgromadzeń nie miałyby takiej szansy dotarcia do adresatów. Gwarantowany jest bowiem w ten sposób podstawowy dla demokracji mechanizm konfrontacji różnych, kontrowersyjnych stanowisk, poglądów i idei, które często nie znajdują zrozumienia u większości społeczeństwa”.

Zgromadzenia w rozumieniu art. 57 Konstytucji różnią się, generalnie rzecz ujmując, od wszelkich innych spotkań jakichś grup ludzkich dwoma cechami. Po pierwsze, wspomnianym już celem, po drugie, istnieniem elementu organizacji. Nie ulega wątpliwości, że wspomniane wyżej zgrupowania ludzkie, które nie sposób zaliczyć do zgromadzeń w rozumieniu art. 57 Konstytucji, także mają pewien cel, ale wydaje się on we wszystkich przywołanych przypadkach inny niż cel leżący u podstaw zgromadzeń, których wolność poręcza Konstytucja. Mają też te zgrupowania organizatora, przynajmniej w pewnym sensie - w przypadku spektaklu teatralnego będzie to dyrekcja teatru, w przypadku mszy świętej - pro- 
boszcz czy biskup, w odniesieniu do meczu kierownictwo klubu itd. Najczęściej w sytuacji, kiedy takie zgrupowanie przekształciłoby się spontanicznie w zgromadzenie, cel ten będzie odległy od tego, jaki przyświecał organizatorowi. Powstaje w tym miejscu bardzo istotne pytanie o to, jakie są obowiązki takiego organizatora. Niekiedy zapanowanie nad emocjami uczestników może nie być łatwe. Wydaje się, że w świetle obowiązujących norm prawnych trudno wymagać od duchownego, aby przewidział możliwość reakcji wiernych i zadbał o bezpieczeństwo uczestników nabożeństwa, i obciążać go odpowiedzialnością za to, że przekształciło się ono po zakończeniu w demonstrację będąca już zgromadzeniem w rozumieniu art. 57 Konstytucji, ale przecież w tej sytuacji niezgłoszone odpowiedniej władzy publicznej. Nie sposób też wymagać, aby dyrekcja teatru przewidziała, jaka będzie reakcja widzów na treść spektaklu (Kotowski, Kurzępa, 2010, s. 75; Szwarc, 1995). Większe obowiązki ciążąjuż z mocy ustawy na organizatorach zawodów sportowych.

Trybunał Konstytucyjny w wyroku z 28 czerwca 2000 r. (wyrok TK z 28 czerwca 2000 r.) wskazał, że termin ,zgromadzenie” obejmuje zebrania, których celem są wspólne obrady lub wspólne wyrażenia stanowiska, bez względu na to, czy ich uczestnicy wyrażają swoje poglądy za pomocą słowa czy też w inny sposób. Sam fakt fizycznej obecności razem z innymi osobami w określonym miejscu może stanowić formę wyrażania przekonań jednostki. Zauważono przy tym, że wolność zgromadzeń należy do tych kategorii praw, których przedmiotem jest każdy człowiek, ale które wykonywane są także kolektywnie, podnosząc, że wolność zgromadzeń oznacza w szczególności swobodę wyboru czasu i miejsca zgromadzenia, formy wyrażania poglądów oraz swobodne ustalanie przebiegu zgromadzenia i prowadzenia obrad. Wolność uczestniczenia w zgromadzeniach oznacza także swobodę odmowy udziału w zgromadzeniu.

Obowiązkiem władz publicznych jest nie tylko usunięcie przeszkód w zakresie korzystania $\mathrm{z}$ tak określonej sfery wolności i zaniechanie nieuzasadnionej ingerencji w tę sferę, ale również podjęcie pewnych kroków pozytywnych mających na celu urzeczywistnienie tego prawa. Zgodnie z orzecznictwem Europejskiego Trybunału Praw Człowieka uczestnicy manifestacji powinni mieć możliwość udziału w niej bez obaw przed aktami przemocy ze strony swoich przeciwników. W judykaturze podkreśla się, że umiejscowienie art. 57 Konstytucji, chroniącego wolność zgromadzeń, w części rozdziału II Konstytucji zatytułowanej Wolności i prawa polityczne, wiąże się ze szczególnym znaczeniem tej wolności dla sfery życia politycznego. Nie upoważnia to jednak do wyciągnięcia wniosku, że 
treść tego przepisu odnosi się wyłącznie do zebrań o charakterze politycznym. $Z$ treści art. 57 Konstytucji wynika, że dotyczy on wszelkich zgromadzeń, a nie tylko politycznych, oczywiście pod warunkiem, że będą one miały charakter pokojowy. Z kolei art. 11 EKPC nakłada na władze publiczne szczególny obowiązek podjęcia działań zapewniających pokojowy przebieg legalnych zgromadzeń (Orzeczenie ETPC Plattform Ärzte für das Leben; Wyroki ETPC: Djavit przeciwko Turcji, Piermont przeciwko Francji). Trybunał w Strasburgu wskazał, że państwo ma pozytywny obowiązek zapewnienia gwarancji proceduralnych ochrony prawa swobodnego, pokojowego zgromadzania się przed nierozsądnymi ograniczeniami ze strony władz publicznych (Wyrok ETPC Éva Molnár przeciwko Węgrom). Warto przy tej okazji zauważyć, że wprawdzie Europejski Trybunał Praw Człowieka nie sformułował pełnej definicji pokojowego zgromadzenia, ale w doktrynie się stwierdza, że chronione prawem zgromadzenie to zgrupowanie przynajmniej dwóch osób dla osiagnięcia wspólnego celu, wspólnie z innymi, w jednym miejscu publicznym i czasie (Wróbel, 2010, s. 693-694). Ochrona konstytucyjna rozciagga się na wszelkie zgromadzenia publiczne, a także prywatne, niezwiązane ze sferą życia publicznego, i to zarówno w pomieszczeniach zamkniętych, jak i na otwartej przestrzeni (wyrok TK z 28 czerwca 2000 r.).

W literaturze się podkreśla, że na wolność zgromadzeń składają się: prawo do zorganizowania zgromadzenia, możność udziału w nim oraz prawo do kierowania zgromadzeniem (Wróbel, 2002, s. 20). Ważną sprawą okazuje się, zarówno w świetle Konstytucji, jak i ustawy z 5 lipca 1990 r. - Prawo o zgromadzeniach, określenie pokojowego charakteru zgromadzenia. Jak wskazał Trybunał Konstytucyjny, ,zgromadzenie pokojowe to zgromadzenie, które przebiega z poszanowaniem integralności fizycznej osób oraz mienia prywatnego i publicznego. Pojęcie »zgromadzenia pokojowego" wyklucza zatem stosowanie przemocy oraz przymusu przez uczestników zgromadzenia, zarówno wobec innych uczestników zgromadzenia, jak i osób trzecich oraz funkcjonariuszy publicznych" (Wyrok TK z 28 czerwca 2000 r.). Podkreślono przy tym, że zarówno Konstytucja, jak i Międzynarodowy pakt praw obywatelskich i politycznych oraz Konwencja o ochronie praw człowieka, zapewniają ochronę wyłącznie zgromadzeniom pokojowym. Przy czym pojęcie zgromadzeń pokojowych należy odnieść do przebiegu zgromadzenia. W orzecznictwie Trybunału Konstytucyjnego wskazano, że fundamentalną cechą demokratycznego standardu wolności zgromadzenia jest pokojowy charakter zgromadzenia i tylko takie zgromadzenia korzystają z konstytucyjnej ochrony. Pokojowy cha- 
rakter zgromadzenia winien być oceniany zarówno w świetle założonego celu, zamiarów organizatorów zgromadzenia, jak i na podstawie przebiegu zgromadzenia. Zasadniczymi elementami treści normatywnej konstytucyjnej wolności zgromadzeń publicznych są: pokojowy charakter zgromadzeń, anonimowość uczestników zgromadzeń publicznych i brak więzów organizacyjnych między nimi, a także między organizatorem zgromadzenia i jego uczestnikami (Wyrok TK z 10 lipca 2008 r.).

Nie wdając się w szczegółową analizę wolności zgromadzeń, wypada zauważyć, że w praktyce, w świetle zdania drugiego art. 57 Konstytucji, możliwe jest ograniczenie tej wolności w przepisach ustawy, a więc przy zastosowaniu standardów określonych w treści art. 31 ust. 3 Konstytucji (Wojtyczek, 1999, s. 179-192). W literaturze się stwierdza, że „społeczeństwo nie mogłoby normalnie funkcjonować, gdyby każdy jego członek mógł w dowolnym jego czasie i miejscu zwoływać w dowolnym celu zgromadzenie dostępne dla nieokreślonej liczby anonimowych osób" (Sokolewicz, 2005, s. 28). Podkreśla się przy tym, że przymiot pokojowości nie jest dany konkretnemu zgromadzeniu raz na zawsze oraz że zgromadzenie z założenia pokojowe i z początku rzeczywiście zachowujące taki charakter ,pod wpływem rozmaitych okoliczności i przy niezbyt sprawnym pokierowaniu przez mało sprawnych lub kierujących się hipokryzją organizatorów łatwo przeradza się w niepokojowy tumult, a nawet staje się zaczynem zamieszek i masowych naruszeń porządku publicznego" (Sokolewicz, 2005, s. 58). Tak więc ograniczenie wolności zgromadzeń może się stać koniecznością. W myśl jednak art. 57 zd. drugie Konstytucji ograniczenie takie może określić ustawa. Warto przy tym pamiętać, iż w myśl wykładni przyjętej przez Trybunał Konstytucyjny każde prawo i każda konstytucyjnie chroniona wolność, z wyjątkiem prawa do godności, mogą być ustawowo ograniczone na ogólnych zasadach sformułowanych w treści art. 31 ust. 3 Konstytucji. Zauważyć należy, że klauzula przewidziana w art. 57 nie formułuje kryteriów ani form ustanawiania ograniczeń, wymaga jedynie, aby były wprowadzone w drodze ustawy. Możliwość wprowadzania takich ograniczeń wynika także w systemie prawa Rady Europy z treści art. 11 ust. 2 EKPC. Wskazano w nim, że przepisy prawa krajowego winny być interpretowane na korzyść prawa pokojowego, swobodnego zgromadzania się (Wyroki ETPC: Oya Ataman przeciwko Turcji, Balcik i inni przeciwko Turcji). Dodaje się niekiedy, że nie powinno dochodzić do zbędnych lub bezpośrednich ograniczeń prawa zgromadzeń oraz że w społeczeństwie demokratycznym opartym na rządach prawa musi być zapewniona odpowiednia możliwość prezen- 
tacji idei stanowiących wyzwanie dla istniejącego porządku przez wykonywanie wolności zgromadzania się (Wyroki ETPC: Stankov przeciwko Bułgarii, Balcik i inni przeciwko Turcji). Termin „ograniczenie” użyty w art. 11 ust. 2 EKPC Trybunał w Strasburgu wykłada jako oznaczający środki podejmowane przed lub w czasie zgromadzenia publicznego oraz środki karne stosowane po zgromadzeniu (Wyrok ETPC Ezelin przeciwko Francji). W judykatach ETPC wskazano, że ograniczenia wolności zgromadzeń nie mogą się opierać na przypuszczeniach, założeniach lub spekulacjach (wyrok ETPC Vajnai przeciwko Węgrom). Podstawą ich może być jedynie akceptowalna, czyli w miarę obiektywna ocena konkretnych faktów (wyroki ETPC: Christian Democratic People's Party przeciwko Mołdawii, Zana przeciwko Turcji). Trybunał podkreślał także, że uzasadnienie ograniczenia musi być relewantne i wystarczające oraz przekonujące i nieodparte (wyroki ETPC: Ouranio Toxo przeciwko Grecji, Barankevich przeciwko Rosji). Jego zdaniem władza publiczna winna przy tym szczegółowo określać podstawy ograniczenia (wyrok ETPC Ivanov i inni przeciwko Bułgarii). Według ETPC wolność swobodnego, pokojowego zgromadzania się, którego celem jest prezentacja poglądów, może być przedmiotem wielu wyjątków, jednak muszą być one interpretowane zawężająco, a wprowadzane ograniczenia przekonująco uzasadnione (wyroki ETPC: Galstyan przeciwko Armenii, Ashughyan przeciwko Armenii). W orzecznictwie Europejskiego Trybunału Praw Człowieka wskazano, że jedynym usprawiedliwieniem ingerencji w wolność zgromadzeń jest konieczność wynikająca z klauzuli „społeczeństwa demokratycznego" (wyroki ETPC: Christian Democratic People's Party przeciwko Mołdawii, Djavit przeciwko Turcji). Wszelkie ograniczenia muszą być przy tym uzasadnione przekonująco i nieodparcie, gdyż państwo z jednej strony ma chronić możliwość pokojowego zgromadzania się, z drugiej powstrzymywać się od stosowania nierozsądnych ograniczeń pośrednich (wyroki ETPC: Adali przeciwko Turcji, Ouranio Toxo przeciwko Grecji).

Niezmiernie ważne wydają się wywody zawarte w uzasadnieniu wyroku Trybunału w sprawie Nurettin Aldemir przeciwko Turcji. W jego treści zauważono, że nie jest naruszeniem art. 11 EKPC wymaganie przez państwo, ze względu na zapewnienie porządku publicznego i bezpieczeństwa państwa, autoryzacji dla odbycia zgromadzenia, jeśli miałoby to służyć ochronie praw innych osób (Wróbel, 2010, s. 710; Stone, 2002, s. 85) przez zapobieżenie nieporządkowi (wyrok ETPC Nurettin Aldemir). W literaturze zauważa się, że wśród przesłanek dopuszczalnych ograniczeń wolności zrzeszania się najistotniejsze znaczenie mają w praktyce wzglę- 
dy ochrony porządku publicznego i chęć zapobieżenia przestępstwom (Stone, 2002, s. 85). Podkreśla się jednak, że prawo do swobodnego udziału w pokojowym zgromadzeniu jest wzmocnione domniemaniem, że jednostka nie może podlegać sankcjom czy nawet najniższym w katalogu karom dyscyplinarnym za udział w zgromadzeniu, które nie było zakazane, dopóki nie popełni przy tej okazji jakiegoś czynu nagannego (wyroki ETPC: Galstyan przeciwko Armenii, Ezelin przeciwko Francji).

W prawie unijnym art. 12 Karty praw podstawowych Unii Europejskiej $^{8}$, przewidując prawo do swobodnego, pokojowego zgromadzania się, nie formułuje możliwości ograniczenia tego prawa. W doktrynie, wskazując, iż prawo do swobodnego zgromadzania się zostało uznane za prawo podstawowe, jako zasada ogólna prawa unijnego (wyrok ETS Schmidtberger Internationale Transporte und Planzüge przeciwko Republik Östericht), podkreśla się, że prawa tego nie narusza podejmowanie rozsądnych i właściwych środków prewencyjnych dla zapewnienia spokojnego przebiegu zgromadzenia, spotkania lub zebrania (Wróbel, 2013, s. 485). Jednocześnie się podkreśla, że na gruncie prawa unijnego mają zastosowanie zasady wypracowane przez Europejski Trybunał Praw Człowieka w Strasburgu wykładający treść art. 11 Karty.

Warto zauważyć, że Trybunał w Strasburgu zdaje się nie rozróżniać dwóch stanów faktycznych, a mianowicie zakazu przeprowadzenia zgromadzenia i sytuacji, gdy wprowadza się pewne ograniczenie nie w sposób generalny, ale w odniesieniu do konkretnego zgromadzenia.

Ograniczenia wolności zgromadzeń przewiduje także art. 21 Międzynarodowego paktu praw obywatelskich i politycznych, wskazując jako ich powód wzgląd na bezpieczeństwo narodowe lub publiczne, porządek publiczny, ochronę zdrowia publicznego lub moralności publicznej albo praw i wolności innych osób. Oczywiście mogą to być tylko ograniczenia wprowadzone ustawą (Gliszczyńska-Grabias, Wiśniewski, 2012, s. 522-538).

Jednym z najistotniejszych problemów dotyczących możliwości ograniczenia wolności zgromadzeń jest sprawa zakazu udziału w zgromadzeniach osób, których nie można zidentyfikować, gdyż są niemożliwe do rozpoznania. Chodzi tu o osoby zamaskowane albo takie, których wygląd zewnętrzny uniemożliwia identyfikację z racji ubioru bądź zmiany wyglądu, np. z powodu zakrycia twarzy czy przebrania się. W efekcie, gdyby biorący udział w zgromadzeniu tak zamaskowany osobnik dopuścił się

8 Karta praw podstawowych Unii Europejskiej (Dz. Urz. UE 2007 C 303/1). 
czynów sprzecznych z prawem, mogłoby to utrudniać, a nawet uniemożliwiać ustalenie jego tożsamości i pociągnięcie do odpowiedzialności. Argument taki, formułowany częstokroć przez niektórych publicystów w środkach społecznego przekazu, a także przez przedstawicieli organów ścigania, jawi się jako co najmniej wątpliwy. Gdyby traktować go poważnie, należałoby stanowczo zakazać noszenia na ulicach takich ubiorów, które utrudniają lub uniemożliwiają jednoznaczną identyfikację jakiejś osoby, gdyż nie można wykluczyć, że naruszy ona prawo. W warunkach trzaskającego mrozu przestrzeganie tego rodzaju przepisów byłoby rzeczą niewątpliwie trudną do egzekwowania, zakładając oczywiście rozsądek odpowiednich służb. Jednocześnie jednak nie da się zaprzeczyć, że biorący udział w rozmaitych legalnych, zgłoszonych odpowiednim władzom i pokojowych zgromadzeniach - różnego rodzaju pochodach, wiecach, przemarszach i mityngach - zakładają kominiarki bądź obwiązują chustami twarz, gdyż udział w zgromadzeniu traktują jako możliwość starcia z policją bądź z uczestnikami kontrmanifestacji. Poważne zniszczenia, jakie tego rodzaju osoby powodują, wywołują chęć ich zidentyfikowania w celu pociagnięcia do odpowiedzialności cywilnej bądź karnej. Nie da się jednak zaprzeczyć, że obywatel biorący udział w pokojowym zgromadzeniu, zamaskowując się, może kierować się obawą, że po rozpoznaniu np. straci pracę, gdyż jego zwierzchnicy nie podzielają jego poglądów, ośmieszy się, jeśli weźmie udział w demonstracji osób, z którymi się identyfikuje, ale których cele nie są akceptowane przez ogół społeczeństwa. Wiele osób żywi obawę, że sfotografowanie ich czy sfilmowanie przez przedstawicieli środków masowego przekazu może narazić ich na ostracyzm w miejscu pracy bądź zamieszkania. Niektórzy chronią swoją prywatność, ale jednocześnie chcieliby się opowiedzieć, i to czynnym udziałem w jakimś zgromadzeniu pokojowym, po stronie określonej idei.

Problem zakazu udziału w zgromadzeniach ludzi zamaskowanych lub takich, których określony ubiór bądź fryzura uniemożliwia identyfikację, był przedmiotem rozważań Trybunału Konstytucyjnego badającego zgodność z Konstytucją art. 1 pkt 1 ustawy z 2 kwietnia 2004 r. o zmianie ustawy - Prawo o zgromadzeniach oraz ustawy - Prawo o ruchu drogowym, zmieniającego art. 3 ust. 2 ustawy z 5 lipca 1990 r. - Prawo o zgromadzeniach $^{9}$, zakazującego uczestnictwa w zgromadzeniach osobom, których wygląd zewnętrzny uniemożliwia ich identyfikację. Trybunał musiał zna-

9 Dz. U. 2004, Nr 51, poz. 297. 
leźć odpowiedź na pytanie, czy wygląd zewnętrzny uczestnika zgromadzenia publicznego, uniemożliwiający jego identyfikację, może stanowić podstawę do ograniczenia wolności organizowania pokojowych zgromadzeń i uczestniczenia w nich. W szczególności także musiał on odpowiedzieć na pytanie, czy takowy zakaz można uznać za konieczny w demokratycznym państwie dla jego bezpieczeństwa lub porządku publicznego albo wolności i praw innych osób. W tej sytuacji koniecznością było zbadanie, czy jego wprowadzenie nie będzie stanowić wartości konstytucyjnych i pogwałcenia art. 31 ust. 3 Konstytucji. Warto w tym miejscu zauważyć, że formułując projekt rozwiązań, kwestionowanej przed Trybunałem ustawy, wskazywano, że jej ratio legis ma zapobiegać uczestnictwu w zgromadzeniach osób zamaskowanych kominiarkami. Podnoszono też, że praktyka stosowania tego przepisu będzie rozsądna i pozwoli odróżnić „pokojowe zamaskowanie” od „niepokojowego” (Biuletyn sejmowej Komisji Administracji i Spraw Wewnętrznych z 23 stycznia 2004 r.). To przekonanie wydaje się dość naiwne i raczej wolno sądzić, że funkcjonariusze odpowiednich służb każde zamaskowanie uznawać będą za sprzeczne z prawem i mające charakter „niepokojowy”. Wskazywano przy tym, że kwestionowany przed Trybunałem przepis będzie dotyczyć tylko osób celowo zamaskowanych, których rodzaj przebrania może sygnalizować agresywne zachowanie.

Trybunał Konstytucyjny w wyroku z 10 listopada 2004 r. (Wyrok TK z 10 listopada 2004 r.), uznając niezgodność kwestionowanych przepisów $\mathrm{z}$ art. 2 oraz art. $57 \mathrm{w}$ zw. z art. 31 ust. 3 Konstytucji, stwierdzil, że zakaz uczestnictwa w zgromadzeniu osób, których przebranie byłoby środkiem wyrażania określonego stanowiska w odniesieniu do jakiegoś problemu, sytuacji czy faktu i nie sygnalizowałoby agresywnego zachowania i ewentualnych zagrożeń dla pokojowego charakteru zgromadzenia, stanowiłby oczywistą nadmierną ingerencję w konstytucyjną wolność uczestniczenia w zgromadzeniach publicznych. Podkreślił przy tym, że pojęcie osoby, której wygląd zewnętrzny uniemożliwia jej identyfikację, pozostawia organom władzy publicznej nadmierną swobodę ustalania ostatecznego kształtu ograniczeń i wyznaczania jej zakresu. Trybunał podkreślił, że wynikający z nowelizacji przepis jest wysoce nieprecyzyjny i niejasny. Jego zakres jest zbyt szeroki w stosunku do intencji samych ustawodawców. Ponadto zaś wprowadza nadmierną ingerencję w wolność uczestnictwa w zgromadzeniach publicznych i nie wskazuje, w jaki sposób niemożność identyfikacji zamaskowanych uczestników mogłaby grozić wartościom wymienionym w art. 31 ust. 3 Konstytucji. W uzasadnieniu Trybunał 
Konstytucyjny podkreślił, że ograniczenie wolności zgromadzeń polegające na ograniczeniu możliwości uczestnictwa w nich w sposób bezimienny, anonimowy nie jest konieczne, gdyż ustawa o Policji z 6 kwietnia 1990 r. (tekst jedn. Dz. U. 2002, Nr 7, poz. 58 ze zm.) daje wystarczające możliwości ingerencji policji $\mathrm{w}$ przebieg zgromadzeń $\mathrm{w}$ przypadku zagrożenia dla ich pokojowego charakteru, w tym także możliwość ustalenia tożsamości osób uczestniczących w zgromadzeniach (art. 15 ust. 1 pkt 1 tej ustawy).

W uzasadnieniu wyroku zwrócono także uwagę na problem, do kogo się odnosi sformułowanie o wyglądzie zewnętrznym uniemożliwiającym identyfikację, w szczególności czy chodzi tu o uczestników zgromadzenia, którzy z własnej woli biorą udział w zgromadzeniu, czy też także o zwykłych gapiów bądź przechodniów, którzy przypadkowo utknęli w thumie. Może się także okazać, iż takie osoby wbrew swojej woli zostają zaliczone do biorących udział w zgromadzeniu. Dodać do tego należy, że do zgromadzenia z natury rzeczy pokojowego mogą się przyłączyć osoby, które absolutnie nie identyfikują się z celami takiego zgromadzenia, ale w udziale w nim widzą możliwość specyficznej rozrywki, jaką stanie się możliwość starcia z policją bądź służbami porządkowymi. Dotyczy to zwłaszcza sytuacji, gdy zgromadzenie odbywa się na otwartej przestrzeni, dostępnej dla nieokreślonych imiennie osób. Pogląd ten kontestowany był w zdaniu odrębnym przez sędziego TK Jerzego Stępnia podnoszącego, że respektowanie anonimowości uczestnika nie może pozbawiać organizatora zgromadzenia możliwości jego zidentyfikowania. Identyfikacja ogranicza wprawdzie wolność uczestniczenia w zgromadzeniu, ale jednocześnie zabezpiecza organizatora zgromadzenia przed odpowiedzialnością za szkody wyrządzone przez zamaskowaną osobę, która niekoniecznie musi się identyfikować z celami zgromadzenia.

W literaturze, komentując omawiany wyrok Trybunału Konstytucyjnego, wskazuje się, że zakaz uczestniczenia w zgromadzeniach przez osoby, których identyfikacja nie jest możliwa, obejmuje także te, które nie stanowiły i nie stanowią zagrożenia dla chronionych konstytucyjnie wartości. Podkreśla się także, że taki zakaz byłby zgodny z Konstytucją jedynie wówczas, gdyby obejmował takich uczestników zgromadzenia, w przypadku których przyczyna braku możliwości ich identyfikacji była bezpośrednio związana z zagrożeniem płynącym z ich strony (Szydło, 2012, s. 123).

Problem możliwości identyfikacji zamaskowanych osób uczestniczących w zgromadzeniach, które dopuszczają się w trakcie ich trwania 
naruszeń porządku, niszczą mienie, powraca praktycznie kilka razy w roku po rozmaitych świętach narodowych. Zachowania uczestników tego rodzaju zgromadzeń świadczą z jednej strony o braku kultury osobistej, zdziczeniu obyczajów, zaniku wszelkich hamulców moralnych i etycznych, braku identyfikacji z porządkiem publicznym, a nawet z państwem. To ostatnie pojmowane jest wielokrotnie jako twór obcy, nienawistny, krępujący wolność. Agresję poszczególnych osób stymuluje częstokroć wypity wcześniej alkohol, a wynika ona $\mathrm{z}$ frustracji, u których podstaw leży niespełnienie oczekiwań, jakie uczestnicy wiązali ze swoją sytuacją życiową. Jest rzeczą jasną, że władze publiczne prędzej czy później będą musiały wybrać między potrzebą ochrony prywatności uczestników zgromadzenia i wolnością organizowania zgromadzeń a potrzebą ochrony porządku publicznego, mienia, zdrowia, a może nawet życia osób niebiorących udziału w zgromadzeniu, które mogą się stać obiektem ataku zamaskowanych, a przez to pewnych swojej nieodpowiedzialności, jego uczestników.

Zgromadzenia publiczne mają w pierwszym rzędzie charakter polityczny, ale nie wolno zapominać, że wpływają one na kształt kultury politycznej całego społeczeństwa, niejednokrotnie zaś służą zwerbalizowaniu stanowisk odnoszących się do rozmaitych zjawisk kulturalnych, będąc wyrazem osobistych przekonań, uprzedzeń i obaw.

\section{Bibliografia}

Biuletyn sejmowej Komisji Administracji i Spraw Wewnętrznych z 23 stycznia 2004 r., nr 2773/4.

Bodnar A., Ziółkowski M. (2008), Zgromadzenia spontaniczne, „Państwo i Prawo”, z. 5. Czarny P., Naleziński B. (1998), Wolność zgromadzeń, Warszawa.

Gliszczyńska-Grabias A., Wiśniewski L. (2012), w: Międzynarodowy Pakt Praw Obywatelskich (Osobistych) i Politycznych. Komentarz, red. R. Wieruszewski, Warszawa.

Gorący A. (1992), Widowisko sportowe - studium agresji, „Roczniki Naukowe AWF”, t. XXIII.

Israel J. (1998), Droits des libertés fondamentales, Paris.

Kotowski W., Kurzępa B. (2010), Bezpieczeństwo imprez masowych. Komentarz do ustawy o bezpieczeństwie imprez masowych, wyd. II, Warszawa.

Kulesza W. (1991), Demonstracja. Blokada. Strajk (Granice wolności zgromadzeń w polskim prawie karnym na tle prawa niemieckiego), Łódź. 
Le Bona G. (1986), Psychologia tłumu, Warszawa.

Mamak K. (2014), Prawo o zgromadzeniach. Komentarz, Warszawa.

Matusewicz S. (1997), Widowisko sportowe, w: Encyklopedia kultury polskiej XX wieku. Kultura fizyczna i sport, red. Z. Krawczyk, Warszawa.

Matusewicz S. (1990), Widowisko sportowe. Analiza psychospołeczna, Warszawa.

Nowakowski A. (2007), Ustawa z dnia 5 lipca 1990 prawo o zgromadzeniach z komentarzem, Wadowice.

Olejniczak-Szałowska E. (2002), Prawo o zgromadzeniach (wybrane problemy), w: E. Ura, Prawne gwarancje ochrony praw jednostki wobec działań administracji publicznej, Rzeszów.

Pawlak A. (1989), Widowisko sportowe jako miejsce badania objawów anomiczności jego uczestników, „Kultura Fizyczna”, nr 9-10.

Robert J. (1988), Libertés publiques et droits de l'homme, Paris.

Rotfeld A. D. (red.) (1989), Prawa człowieka. Międzynarodowe zobowiazania Polski (wybór dokumentów), Warszawa.

Sokolewicz W. (2005), Uwagi do art. 57 Konstytucji, w: Konstytucji Rzeczypospolitej Polskiej. Komentarz, t. IV, red. L. Garlicki, Warszawa.

Stone R. (2002), Textbook on Civil Liberties and Human Rights, Oxford.

Symonides J. (2004), Wolność akademicka jako kategoria praw człowieka: o potrzebie przyjęcia instrument międzynarodowego, w: Księga Jubileuszowa Profesora Tadeusza Jasudowicza, red. J. Białocerkiewicz, M. Balcerzak, A. Czeczeczko-Durlak, Toruń.

Szwarc A. (1995), Naruszenia porzadku towarzyszace imprezom sportowym, Poznań.

Szydło M. (2012), Opinia prawna na temat projektu ustawy o zmianie ustawy-Prawo o zgromadzeniach, ,Zeszyty Prawnicze”, nr 2(34).

Ura E. (2013), Komentarz do art. 230 ustawy prawo o szkolnictwie wyższym, w: Prawo o szkolnictwie wyższym. Komentarz, red. W. Santera, M. Wierzbowski, Warszawa.

van Dijk P., Hoof G. J. H. van (1998), Theory and Practice of the European Convention on Human Rights, wyd. 3, The Hague.

Wojtyczek K. (1999), Granice ingerencji ustawodawczej w sfere praw człowieka w Konstytucji RP, Kraków.

Wróbel A. (2010), Uwagi do art. 11 Europejskiej Konwencji o Ochronie Praw Człowieka i Podstawowych Wolność, w: Konwencja o Ochronie Praw Człowieka i Podstawowych Wolności. Komentarz do art. 1-18, t. I, red. L. Garlicki, Warszawa.

Wróbel A. (2013), Uwagi do art. 12 Karty Praw Podstawowych, w: Karta Praw Podstawowych Unii Europejskiej. Komentarz, red. A. Wróbel, Warszawa.

Wróbel A. (2002), Wolność zgromadzania się, w: Wolności i prawa polityczne, red. M. Chmaj, Kraków. 


\section{Orzecznictwo}

\section{ETPCz}

Orzeczenie Europejskiego Trybunału Praw Człowieka w Strasburgu w sprawie Plattform Ärzte für das Leben, wyrok z dnia z 21 czerwca 1988 r., skarga nr 10126/02, http://hudoc.echr.coe.int/sites/eng/pages/search.aspx?i=001-57558, odczyt 1.05.2014, 14:27; Publications of the European Court of Human Rights. Series A: Judgements and Decisions, nr 139, 32.

Wyrok Europejskiego Trybunału Praw Człowieka w sprawie Adali przeciwko Turcji, wyrok z dnia 31 marca 2005 r., orzecz. ostateczne 12 października 2005 r., skarga nr 38187/97, http://hudoc.echr.coe.int/sites/eng/pages/search.aspx?i=001-68670.

Wyrok Europejskiego Trybunału Praw Człowieka w sprawie Ashughyan przeciwko Armenii, wyrok z dnia 17 lipca 2008 r., skarga 33268/03, http://hudoc.echr.coe.int/ sites/eng/pages/search.aspx?i=001-87642, odczyt 1.05.0214, 16:20.

Wyrok Europejskiego Trybunału Praw Człowieka w sprawie Balcik i inni przeciwko Turcji, wyrok z dnia 26 kwietnia 2005 r., orzecz. ostateczne 26 lipca 2005 r., skarga nr 63878/00, http://hudoc.echr.coe.int/sites/eng/pages/search.aspx?i= 001-68888, odczyt 1.05.2014, 15:54.

Wyrok Europejskiego Trybunału Praw Człowieka w sprawie Barankevich przeciwko Rosji, wyrok z dnia 20 października 2005 r., skarga nr 10519/03 http://hudoc.echr.coe.int/sites/eng/pages/search.aspx?i=001-71243, odczyt 1.05.0214, 16:15.

Wyrok Europejskiego Trybunału Praw Człowieka w sprawie Christian Democratic People's Party przeciwko Mołdawii, wyrok z dnia 14 lutego 2006 r., skarga nr 28793/02, http://hudoc.echr.coe.int/sites/eng/pages/search.aspx?i=001-72346, odczyt 1.05.0214, 16:08.

Wyrok Europejskiego Trybunału Praw Człowieka w sprawie Ezelin przeciwko Francji, wyrok z dnia 26 kwietnia 1991 r., skarga nr 11800/85, http://hudoc.echr.coe.int/sites/eng/pages/search.aspx?i=001-57675, odczyt 1.05.2014, 16:06.

Wyrok Europejskiego Trybunału Praw Człowieka w sprawie Galstyan przeciwko Armenii, wyrok z dnia 15 listopada 2007 r., skarga nr 26986/03 http://hudoc.echr.coe.int/sites/eng/pages/search.aspx?i=001-83297, odczyt 1.05.0214, 16:19.

Wyrok Europejskiego Trybunału Praw Człowieka w sprawie Ivanov i inni przeciwko Bułgarii, wyrok z dnia 24 listopada 2005 r., skarga nr 46336/99 http://hudoc.echr.coe.int/sites/eng/pages/search.aspx?i=001-71297, odczyt 1.05.0214, 16:16.

Wyrok Europejskiego Trybunału Praw Człowieka w sprawie Nurettin Aldemir przeciwko Turcji, z dnia 18 grudnia 2007 r., orzeczenie ostateczne z 2 czerwca 
2008 r., nr skargi 32124/02, 32126/02, 32129/02, 32132/02, 32133/02, 32137/02 and 32138/02, http:/hudoc.echr.coe.int/sites/eng/pages/search.aspx?i=001-84054, odczyt 1.05.2014, 16:30.

Wyrok Europejskiego Trybunału Praw Człowieka w sprawie Ouranio Toxo przeciwko Grecji, wyrok z dnia 20 października 2005 r., orzecz. ostateczne 20 czerwca 2006 r., skarga $\mathrm{nr}$ 74989/01, http://hudoc.echr.coe.int/sites/eng/pages/search.aspx?i=001-70720, odczyt 1.05.0214, 16: 11 .

Wyrok Europejskiego Trybunału Praw Człowieka w sprawie Oya Ataman przeciwko Turcji, wyrok z dnia 5 grudnia 2006 r., orzecz. ostateczne 5 marca 2007 r., skarga $\mathrm{nr}$ 74552/01, http://hudoc.echr.coe.int/sites/eng/pages/search.aspx?i= 001-78330, odczyt 1.05.2014, 15:52.

Wyrok Europejskiego Trybunału Praw Człowieka w sprawie Stankov przeciwko Bułgarii, wyrok z dnia 2 października 2001 r., orzecz. ostateczne 2 stycznia 2002 r., skargi numer 29221/95 29225/95, http://hudoc.echr.coe.int/sites/ eng/pages/search.aspx?i=001-59689, odczyt 1.05.2014, 16:02.

Wyrok Europejskiego Trybunału Praw Człowieka w sprawie Vajnai przeciwko Węgrom wyrok z dnia 8 lipca 2008 r., skarga nr 33629/06, http://hudoc.echr.coe.int/ sites/eng/pages/search.aspx?i=001-87404, odczyt 1.05.0214, 16:07.

Wyrok Europejskiego Trybunału Praw Człowieka w sprawie Zana przeciwko Turcji, wyrok z dnia 25 listopada 1997 r., skarga nr 18954/91, http://hudoc.echr. coe.int/sites/eng/pages/search.aspx?i=001-58115, odczyt 1.05.0214, 16:10.

Wyrok Europejskiego Trybunału Praw Człowieka w Strasburgu w sprawie Young, James, Webster przeciwko Zjednoczonemu Królestwu, wyrok z dnia 13 sierpnia 1981 r., skargi nr 7601/76 7806/77, http://hudoc.echr.coe.int/sites/eng/pages/search.aspx?i=001-62164, odczyt 1.05.2014, 14:00.

Wyrok Europejskiego Trybunału Praw Człowieka w Strasburgu w sprawie Kazantseva przeciwko Rosji, wyrok z dnia 23 października 2008 r., skarga nr 26365/05; http:/hudoc.echr.coe.int/sites/eng/pages/search.aspx?i=001-89040, odczyt 1.05.2014, 14:10.

Wyrok Europejskiego Trybunału Praw Człowieka w Strasburgu w sprawie Éva Molnár przeciwko Węgrom, wyrok z dnia 7 października 2008 r., ostateczna decyzja 7 stycznia 2009 r., skarga nr 10346/05, http://hudoc.echr.coe.int/sites/ eng/pages/search.aspx?i=001-88775, odczyt 1.05.2014, 14:17.

Wyrok Europejskiego Trybunału Praw Człowieka w Strasburgu w sprawie Djavit przeciwko Turcji, wyrok z dnia 20 lutego 2003 r., ostateczna decyzja 9 lipca 2003 r., skarga nr 20652/92, http://hudoc.echr.coe.int/sites/eng/pages/search.aspx?i=001-60953, odczyt 1.05.2014, 14:19.

Wyrok Europejskiego Trybunału Praw Człowieka w Strasburgu w sprawie Piermont przeciwko Francji, wyrok z dnia 27 kwietnia 1995 r., skargi nr 15773/89 15774/89, http://hudoc.echr.coe.int/sites/eng/pages/search.aspx?i=001-57925, odczyt 1.05.2014, 15:11. 


\section{Trybunal Sprawiedliwości}

Wyrok Europejskiego Trybunału Sprawiedliwości z dnia 12 czerwca 2003 r. w sprawie C-112/00, Schmidtberger Internationale Transporte und Planzüge przeciwko Republik Östericht, Zbiór Orzeczeń 2003, s. I-5659

\section{Trybunal Konstytucyjny}

Wyrok Trybunału Konstytucyjnego z dnia 10 lipca 2008 r. P 15/08, OTK-A 2008, nr 6, poz. 105, Lexis.pl nr 1925181.

Wyrok Trybunału Konstytucyjnego z dnia 10 listopada 2004 r., Kp 1/04, OTK-A 2004, nr 10 , poz. 105 .

Wyrok Trybunału Konstytucyjnego z dnia 18 stycznia 2006 r., K 21/05, OTK-A 2006, nr 1, poz. 4, Lexis.pl nr 397795.

Wyrok Trybunału Konstytucyjnego z dnia 28 czerwca 2000 r., K. 34/99, OTK ZU 2000, nr 5, poz. 142, Lexis.pl nr 347757.

Wyrok Trybunału Konstytucyjnego z dnia 28 czerwca 2000 r., sygn. akt K 34/99, OTK ZU 2000, nr 5, poz. 142.

\section{Public assemblies in the Polish legal system and their significance for culture and arts}

\section{Summary}

Freedom of assembly is provided by Article 57 of the Constitution, as well as by numerous acts of international law. Neither the term "assembly" nor the provisions concerning the restrictions on the freedom of assembly seem to be entirely clear in the Polish legal system. Within the legal system of the Council of Europe, the European Court of Human Rights in Strasbourg has tried to define these matters. What raises particular controversy in Poland is the issue of whether assemblies can be attended by people wearing masks, who cannot therefore be identified. The attempts to change this situation have failed as a result of the position taken by the Constitutional Tribunal, but the issue seems likely to be raised again in the future. 